\title{
The Cultivation of College Students' "Life - Iong Physical Education" Through the Inheritance and Development of College Sports Culture ------A Case Study of the Twenty - second National Fitness Festival of Southwest Petroleum University
}

\author{
Xiangqi Tang ${ }^{1}$ and Yingshu $\mathrm{Hu}^{2}$ \\ ${ }^{1}$ School of Physical Education, Southwest Petroleum University, Chengdu 610000, Sichuan \\ Province, China; \\ ${ }^{2}$ Southwest Petroleum University, Chengdu 610000, China
}

\begin{abstract}
Colleges are an important base for developing moral, intellectual, physical and aesthetic high quality talents in China, there in, the construction of campus sports culture plays an irreplaceable and long-term role in cultivating new talents. As the final stage of school physical education activities, the higher education plays a connecting role in cultivating the "lifelong sports concept", is the connecting point to implement lifelong sports base for college students and the necessary link to cultivate college students lifelong sports concept. Nowadays, in the face of the current college students increasingly behavior of neglecting the physical exercise and the weak awareness of fitness, the campus sports culture construction is urgent and imperative. Good campus sports culture plays a positive role in promoting teaching and educating people, it allows college students to get a comprehensive and healthy development in health, learning, sports, values, spiritual style and so on, pooling the fresh blood into socialist modernization. Therefore, the inheritance and development of college sports culture is of vital importance to the development of students' physical and mental development and the construction of campus culture. In this paper, through the "Twenty-second National Fitness Festival", the author analyzed the ideas and path of the inheritance and development, reform and construction of campus sports culture in colleges of China, so as to better promote the development of college students' physical and mental health, making college students develop "lifelong sports concept", and develop a good habit of physical exercise, thus accelerating the development of national fitness.
\end{abstract}

Keywords: College sports culture; Inheritance and development; Lifelong sports view; National fitness; Sports festival

\section{高校体育文化传承与发展对大学生“终身体育观”}

\section{的培养}

一以西南石油大学二十二届全民健身体育节为例 唐湘琪 ${ }^{1}$, 胡英姝 ${ }^{2}$

( 1. 西南石油大学体育学院, 四川省成都市, 邮编 610000; 2. 西南石油大学, 四川省成都市, 邮编 610000 )

摘要: 高校是我国培养德、智、体、美全方位人才发展的重要基地，其中校园体育文化建设在培养新型人才方面起着不 可替代和长远的影响作用, 高校作为学校体育教育活动的最后阶段, 对于大学生培养 “终于体育观” 起着承前启后的衔接作 用, 是大学生实施终身体育基础的重要连接点和培养大学生终身体育观的必要环节。如今, 面对当下大学生日渐忽视体育锻 炼行为和健身意识的薄弱, 进行高校校园体育文化建设是刻不容缓的, 也是势在必行的。良好的校园体育文化对于教书育人 将起着积极的促进作用, 它能让大学生的健康观、学习观、体育观、价值观、精神风貌等得到全面的健康发展, 更能为我国 社会主义现代化建设的人才储备注入新鲜的血液。因此, 高校体育文化的传承与发展对于学生身心的发展和校园文化的建设 是至关重要的。文中通过以“西南石油大学二十二届全民健身体育节” 为案例, 展开对我国高校校园体育文化传承与发展、 
改革与建设的思路和路径分析, 以便更好的促进大学生身心健康发展, 树立大学生 “终身体育观”, 养成良好的体育锻炼习

惯，从而加速全民健身的发展。

关键词：高校体育文化；传承与发展；终身体育观；全民健身；体育节

\section{引言}

当代大学生是我国社会主义现代化建设的中流砥柱, 具有强烈的责任感和时代的使命感, 他们的健康 体质和身心发展问题直接关系到了国家未来的发展。但是, 我国大学生的健康状况却差强人意, 不容乐观。 随着社会经济的发展, 电子科技产品的进步, 大学生们的生活习惯和诸多不良嗜好也随之引发了一系列的 健康问题，根据我国教育部近些年来检测结果公示，主要问题出现在以下方面:

第一：身体体能指标（力量、速度、耐力、协调、柔韧等素质）出现逐步下滑趋势，因此，2014 年特 将引体向上和仰卧起坐作为大学生体质测试的必测项目。

第二: 视力不良率, 大学生为 $84.72 \%$, 其中城市为 $84.14 \%$, 农村为 $85.30 \%$, 视力不良率逐步呈上涨 趋势, 居高不下。

第三：生活作息规律不良和饮食不节制，导致体重超标，肥胖率逐步呈上涨趋势，易诱发心脑血管疾 病、高血压、糖尿病等不良疾病。

体育健身锻炼是提高人体免疫功能、改善人体机能、促进身心健康发展的最有效途径, 针对大学生现 今存在的体质健康问题, 我国各大高校应该主动承担肩上的责任和充分发挥其各职能部门关于校园体育文 化的建设作用, 与时俱进, 深化体育改革和加强体制创新, 对大学生的体育行为活动进行有效的积极引导, 对于大学生的体育锻炼时间和体育器材设备给予充分的保障, 因为, 良好的体育锻炼习惯将会有效的改善 大学生们的身体健康, 有效的提高学习效率, 对他们日后的身体状况、学习生活和工作适应能力都将起着 重要的意义。

\section{1 我国高校体育文化传承与发展的现状思考}

高校体育文化的传承为了更好的继承和发展，是为了提高体育教育手段对人们未来工作、生活行为方 式的指导, 培养学生树立 “终身体育观” 的行为意识。然而, 现今高校体育文化在不同学校、不同时期和 不同环境下, 使体育在学校的身份、地位和学校体育实施力度与重视程度都将形成不同的体育价值观, 这 也将直接导致学生受体育教育的程度如何, 影响着学生们对体育锻炼行为的意识取向。现今, 大学生体质 健康呈下降趋势, 究其原因不仅在于家庭遗传因素、个人成长环境、饮食生活习惯等因素, 更在于大学生 的体育受教育程度和个人体育健身行为观念和良好的锻炼习惯, 而此时, 大学校园体育文化在其中则扮演 了重要的角色, 一所底蕴深厚、德智体美兼备的大学应该是具备了丰富的校园文化活动, 对体育文化进行 着不断的传承和发展。而现今, 当代大学生所处于日益激烈的社会, 各个高校在重视学生文化基础、教师 科研项目、学生就业工作的同时却忽略了大学生的体质健康问题, 这也是我国高校现今存在的矛盾问题, 所以，高校体育文化在传承和发展的同时，也应与时俱进，“去其糟粕，取其精华”，积极深化体育全面 创新改革, 对学生的发展不仅要做到 “文明其精神” , 也要做到 “野蛮其体鬼” , 这样才能更好的适应当 前竞争激烈的社会。

\section{2 以西南石油大学全民健身体育节探讨我国高校体育教育改革思路}

1995 年 6 月, 国务院颁发了《全民健身计划纲要》，当时，全国上下对于健身意识都相对于薄弱，而 
就在当年, 西南石油大学紧跟时代号角, 举办了第一届全民健身体育节, 即便是在 2003 年的 “非典” 和 2008 年汶川地震困难时期, 体育节也没有中断, 且每年如期举办。“二十二年磨一剑” , 发展至今已成功 举办二十二届, 并于 2015 年以师生赞誉口碑和绝对评选优势从 23 项西南石油大学校园文化成果奖评选中 荣获 “校园文化成果一等奖”, 其次, 中国教育报高等教育周刊改革探索版面, 还对我校体育文化活动进 行了图片报道。每年体育节持续时间为近一个半月, 活动内容丰富, 深受师生好评和喜爱, 其中教工集体 运动项目包括: 环校健康快步走、气排球、拔河、跳绳、毛毛虫竞跑、同心鼓; 学生运动项目包括: 羽毛 球、乒乓球、篮球、排球、拔河、跳绳、同心鼓、有轨电车、毛毛虫竞跑、男子象棋、女子五子棋, 而收 官之作将会以坐无缺席、精彩绝伦的体育舞蹈大赛来作为本届全民健身体育节的闭幕式。因此, 每年初冬, 体育节就相当于全校师生联欢盛宴、师生齐聚总动员, 是我校师生参与人数对多、校园文化建设、体育健 身性和趣味活动性最强的品牌校园文化活动。不仅如此, 西南石油大学在 “十三五期间” 后, 不断在体育 教育工作层面还做出了积极的全面深化改革, 现今已引入 “体育科学与健康大数据实验室、学生四百公里 健身跑、大学生公共体育健身俱乐部” , 形成了课内 “体能达标与测试+两门专项课+体育俱乐部” 与课外 “400 公里健身跑” 相结合的一体化课程模式, 作为西南石油大学校长赵金洲同时也鼓励全校师生: “希 望全校师生投入到科学健身热潮中, 牢固树立 “终身体育、健康第一” 的观念, 养成良好的体育锻炼习惯, 建立健康的生活行为方式, 为建设高水平特色大学和百年名校贡献更大的力量”。

\section{3 塑造高校 “校园体育文化品牌” , 促进师生 “人人入队”}

习近平总书记说过: “推动中国产品向中国品牌转变” 的指导思想, 而作为国家电视台, 央视肩负着 培育下一个 30 年代表中国经济实力的国家品牌的重任。“国家平台成就国家品牌” 的提出与实施, 正是 我国品牌最需要的绿色成长养分。校园体育文化品牌也亦是如此, 高校肩负着培育一代一代的新型人才, 他们都是我国中流砥柱的后备力量。因此, 高校必须全新规划和打造校园文化, 加快体育设施建设, 丰富 校园文化生活, “促进师生人人入队”, 积极建设 “校园体育文化品牌” 的塑造, 让体育成为学生们的一 种生活方式, 为我国各高校莘莘学子们提供新鲜成长的养分。

现今, 国内外高校对于校园体育文化品牌建设越发重视, 例如: 西南石油大学二十二届全民健身体育 节, 师生人人入队; 山东大学品牌学校研究所, 负责学校品牌文化和形象传播; 四川大学全国高校 Mini 马拉松暨四川大学第十四届环校跑, 倡导绿色健康体育活动; 清华大学 “光荣与梦想一奥林匹克培训计划, 传递奥林匹克精神。这些计划和措施, 都加将会加快校园体育文化建设, 能为全校师生体育锻炼创造更好 的条件。而塑造高校体育文化品牌路径则在以下几点方面体现:

\section{1 丰富校园体育精品文化活动, 加强校园体育文化的宣传力度}

首先, 学校层面应该积极加强对体育文化的构建和体育器材设备的资金扶持, 极引进精品体育项目, 拓展体育健身渠道, 每年的校园文化活动中都应如期坚持体育文化活动的开展, 通过各职能部门的引导、 宣传栏通告、网络信息等方式, 加强对相关健身知识、体育活动、体育赛事等方面的宣传力度, 鼓励师生 重视体育文化, 积极参与体育锻炼, 做好校园体育文化活动的传承与发展。

\section{2 提高校园文化活动的奖励机制, 鼓励师生参与}

体育不单纯是肢体的运动, 更是一种思想和精神的体现。阳光体育既有健身休闲作用, 也有奋进拼搏、 竞技比拼的一面, 高校应加大奖励机制, 通过多种鼓励途径, 如设立: 十佳阳光体育明星、体育工作优秀 
学院、校工会优秀体育协会、最佳体育摄影奖等举措来鼓励师生齐聚参与。

\section{3 落实师生体育俱乐部、协会社团的组建、培育和指导工作，加强对师生的指导工作}

高校体育俱乐部、师生体育社团和协会、大学生公共体育课程等作为校园体育文化活动的载体，关乎 着全体师生的体育锻炼活动和健康实施的开展, 而作为体育人, 亦或者体育爱好者都应该集结一心共同致 力于学校健康的发展, 积极带动我校运动健身的思潮, 有效引导学校师生进行体育锻炼的指导, 促进师生 健康体质的发展, 为营造校园体育文化活动氛围做出伟大的贡献。

\section{4 全面深化体育教育改革, 培养大学生 “终身体育观”}

我国高校体育教育改革，一直是我们国家关心的健康素质大问题，因此，于 2014 年我国国务院就印 发了《关于加快发展体育产业促进体育消费的若干意见》, 文中提出将 “全民健身” 上升为国家战略, 而 为了更进一步促进我国公民体育健身的意识和加快体育产业的发展, 于 2016 年国务院又发布《“健康中 国 2030” 规划纲要》，文中强调 “将健康教育纳入国民教育体系，把健康教育作为所有教育阶段素质教育 的重要内容”, 所以, 体育教育改革不仅关乎学校, 更关乎国家。改革之路总是步履蹒跚, 异常艰辛, 高 校在体育教育改革之路也是如此, 能否与时俱进符合现代大学生的健身需求、能否真切引导大学生 “走出 寝室, 走向操场” 、能否实际关心每一位大学生体质健康问题、能否有效改善大学生健康体质素质, 这些 都是需要不断推敲、摸索、创新和全面贯彻落实的。然而, 实际上, 我国高校体育文化活动还存在诸多问 题和弊端, 这非常不利于大学生体质健康的促进, 更不利于大学生今后养成 “终身体育” 锻炼的行为。因 此，体育教育改革思路应体现在:

\section{1 加强高校构建大学生体育教育立体化信息网络, 实现终身 “渗透式” 教育}

高校体育教育全面深化改革中, 课程内容设置, 只是前进的 “一小步” , 公共体育教育面对全校数万 大学生, 人数众多、数据庞大、课程繁多, 管理存在一定的困难, 构建大学生体育教育立体化信息网络管 理, 改善高校体育教学管理系统, 将准确和有效得到校园体育健康大数据, 对学生体质数据还能进行清晰 的信息化管理, 不仅让老师的工作更有效率, 还能让更多学生受益, 其次, 借助网络信息时代的便捷, 通 过体育教学网络资源整合、学生多元评价体系、网络建设理论题库、推出网络学习平台等方式, 使我过各 大高校都能够逐步构建起学生体育教育的立体化网络, 实现 “渗透式” 教育, 让每一位大学生都能够得到 良好的体育教育, 并掌握体育一技之长, 为终身体育打好基础。

\section{2 以大学生兴趣为导向, 找准发力点, 打出 “组合拳”}

兴趣是学习行为的动力, 是行为意识中最活跃的营养成份。大学生的教育遵循个性发展, 体育课程设 置坚持以大学生兴趣为导向, 将有利于提高学生学习的积极主动性, 激发学生的运动细胞, 以便让学生更 好的吸收和学习课堂内容。而作为教育者, 就必须快速找准时代日益更新的体育健身需求, 跟紧时代的潮 流, 通过拓展知识结构, 丰富体育健身活动, 构建校园体育文化等渠道措, 打出 “组合拳” , 营造良好的 运动健身氛围, 让学生能够从体育教育中感受到体育知识的更新和运动健身方式的改变, 增强学生们对体 育健身活动的主动热爱。

\section{3 让大学生认识体育、参与体育、享受体育, 使运动成为一种生活方式}

体育不仅是肢体的锻炼, 更是思想和精神的凝聚。体育让人强身健体, 但体育背后的故事也让人为之 动容, 让大学生认识体育, 感受体育精神, 不单纯的表现在肢体动作的教学上, 也应该建立在坚持、奋进、 
拼搏的强大意志上, 作为体育人, 有职责, 也有使命把体育精神让大学生亲身感受, 让他们敢于超越, 享 受体育洗礼，使运动成为一种生活方式，让 “终身体育观”形成一种习惯。

\section{5 结论}

无论何时何地, 高校体育文化建设都应该是校园文化活动建设的重要组成部分，因为它是促进大学生 身心健康发展的高效途径，能够锻炼大学生们坚强意志，培养积极向上、奋勇拼搏的精神和独立健全的人 格。高校作为体育文化传承和发展的载体, 应该与时不断创新, 结合学校办学特色, 全面深化体育教育改 革, 努力打造出属于自我高校建设的体育校园文化品牌活动, 为大学生们的体育文化提供丰富多样的课程 与活动, 为大学生们的健康体质提供有力的保障, 为体育在我国高校校园文化活动做出世代的传承与发展, 从而树立大学生们 “终身体育观”。

\section{参考文献}

[1]施鹏飞. 高校校园体育活动的品牌化开发研究[A]. 中国体育科学学会(China Sport Science Society).第九届全国体育科 学大会论文摘要汇编(2)[C].中国体育科学学会(China Sport Science Society):,2011:1.

[2] 游江波.体育教学有效促进学生体育习惯养成的研究[J].体育与科学, 2009

[3]王培智. 校园体育文化对大学生树立终身体育观的影响[J]. 科技信息,2009,(35):512+515.

[4] 邱欣. 高校校园体育文化对大学生人文精神影响的研究[D].广西师范大学,2007.

[5]王秀强. 我国百年名校校园体育文化的传承与发展研究[D].上海交通大学,2010.

[6]李萍. 全国石油高等院校学校体育现状及其对策研究[D].北京体育大学,2004.

[7]杨昌林. 《体育之研究》在深化学校体育教育改革中的指导地位[A]. 中国体育科学学会.第六届全国体育科学大会论 文摘要汇编（二）[C].中国体育科学学会:2000:2.

\section{References:}

[1] Shi Pengfei. Study on the brand development of campus sports activities in colleges and universities [A]. China Sports Science Society (China Sport Science Society). Ninth National Sports Science Conference abstracts (2) [C]. China Sports Science Society (China Sport Science Society) 2011: 1 .

[2] You Jiangbo. Effects of physical education on the cultivation of students' sports habits [J]. Journal of Sports and Science, 2009

[3] Wang Peizhi. Effects on college students to establish lifelong sports value by campus sports culture on [J]. Science and Technology Information, 2009, (35): 512 -515.

[4] Qiu Xin. The impact on college students humanistic spirit by college campus sports culture on of [D]. Guangxi Normal University, 2007.

[5] Wang Xiujiang. Research on campus sports culture heritage and development in China's famous university [D]. Shanghai Jiaotong University, 2010.

[6] Li Ping. Current situation and countermeasures of physical education of national petroleum institute [D]. Beijing University of Sport, 2004.

[7] Yang Changlin. The guiding position of "Sports research" in the deepening of the school physical education reform [A]. China Sports Science Society. Sixth National Sports Science Conference abstract summary (2) [C]. China Sports Science Learn, 2002, 2. 